\title{
Biophysics in Latin America
}

\author{
Pietro Ciancaglini ${ }^{1} \cdot{\text { Rosangela } \text { Itri }^{2}}^{2}$
}

Received: 29 August 2017 / Accepted: 4 September 2017 /Published online: 16 September 2017

(C) International Union for Pure and Applied Biophysics (IUPAB) and Springer-Verlag GmbH Germany 2017

Following the special issue coordinated by Morales and Alonso, Successful Latin American initiatives in biophysics (Morales \& del Valle Alonso, 2014), this is another action to promote the biophysics research that takes place in Latin America, with the focus on the IUPAB Congress in 2020 (http://www.sbbq.org.br/iupab2020, n.d.).

The Latin American Federation of Biophysical Societies (LAFeBS) and POSLATAM were founded in 2007 to encourage the development and dissemination of the biophysics area. Nowadays, the Federation involves Biophysical Societies and groups of researchers from the following countries: Argentina, Brazil, Colombia, Portugal, Spain, Uruguay, Venezuela and Cuba (http://www.lafebs.org, n.d.).

The plan for this Special Issue catalyzed by Cris dos Remedios (Editor in Chief) started one year ago. Several researchers were invited from all the countries of Latin America to contribute. With satisfaction, we acknowledge

This article is part of a Special Issue on 'Latin America' edited by Pietro Ciancaglini and Rosangela Itri.

Pietro Ciancaglini

pietro@ffclrp.usp.br

$\triangle$ Rosangela Itri

itri@if.usp.br

1 Depto. Química, Faculdade de Filosofia, Ciências e Letras de Ribeirão Preto da Universidade de São Paulo, FFCLRP-USP, Ribeirão Preto, São Paulo, Brazil

2 Depto. Física Aplicada, Instituto de Física, IF-USP, Universidade de São Paulo, São Paulo, SP, Brazil all authors who kindly accepted our invitation to write a review in biophysical-related areas of expertise. With their valuable contributions ( 26 review papers in total), the main research areas are highlighted here and reflect the panorama of biophysics in Latin America. They comprise: Molecular Machinery; Protein-Nucleic Acid Interactions; Protein Structure to Function; Computational Biophysics; Experimental and Computational Approaches to Protein Design; Protein Misfolding; Membrane Permeation: Channels and Transporters; Biomimetic Structures and Systems (Nanobiophysics); Drug Discovery and Delivery; Protein Folding and Assembly; Applications in Biomedical and Materials Science; Membrane-Active Peptides; Physics of Cancer; and Photodynamic Therapy (Table 1 lists the content of the Special Issue), with reviews from Cuba (1), Venezuela (2), Uruguay (2), Argentina (6) and Brazil (15).

In spite of intermittent resources which feed science in Latin America (Petherick, 2017), this Special Issue demonstrates the quality of the work developed in Latin America in the frontier of knowledge (https://www.thomsonreuters.com/ en.html, n.d.). Furthermore, as biophysics permeates more than one area of expertise, with the appliance of different methodologies, the research is often carried out by multidisciplinary teams with strong international cooperation.

Therefore, the presence of Latin America's leading scientists among the invited writers certainly contributes to creating a very rich environment, which we are certain allows for bringing together the best of science in biophysics in development in Latin America.

Enjoy reading!

Pietro and Rosangela. 
Table 1 of MS accepted in the SI

\begin{tabular}{|c|c|c|c|}
\hline Order & Country & $\begin{array}{l}\text { Corresponding } \\
\text { author }\end{array}$ & Article title \\
\hline 01 & Venezuela & Padrón & $\begin{array}{l}\text { Lessons from a tarantula: new insights into myosin interacting-heads motif evolution and its implications on } \\
\text { disease }\end{array}$ \\
\hline 02 & Venezuela & Padrón & $\begin{array}{l}\text { Lessons from a tarantula: new insights into muscle thick filament and myosin interacting-heads motif structure and } \\
\text { function }\end{array}$ \\
\hline 03 & Brazil & Garratt & Septin structure and filament assembly \\
\hline 04 & Argentina & Chehin & Lessons learned from protein aggregation: toward technological and biomedical applications \\
\hline 05 & Brazil & Lopes & Going deep into protein secondary structure with synchrotron radiation circular dichroism spectroscopy \\
\hline 06 & Cuba & $\begin{array}{l}\text { Alvarez } \\
\quad \text { Valcarcel }\end{array}$ & $\begin{array}{l}\text { Biophysical and biochemical strategies to understand membrane binding and pore formation by sticholysins, } \\
\text { pore-forming proteins from a sea anemone }\end{array}$ \\
\hline 07 & Argentina & Amodeo & Plant and animal aquaporins crosstalk: what can be revealed from distinct perspectives \\
\hline 08 & Argentina & Flecha & Kinetic stability of membrane proteins \\
\hline 09 & Uruguay & Marin & Protein folding and tRNA biology \\
\hline 10 & Argentina & Fanani & The many faces (and phases) of ceramide and sphingomyelin I: single lipids \\
\hline 11 & Argentina & Fanani & The many faces (and phases) of ceramide and sphingomyelin II: binary mixtures \\
\hline 12 & Brazil & Cuccovia & Counting ions and other nucleophiles at surfaces by chemical trapping \\
\hline 13 & Brazil & Lamy & Structural insights on biologically relevant cationic membranes by ESR spectroscopy \\
\hline 14 & Brazil & De Paula & $\begin{array}{l}\text { Biophysical approaches in the study of biomembrane solubilization: quantitative assessment and the role of lateral } \\
\text { inhomogeneity }\end{array}$ \\
\hline 15 & Brazil & Neto & Lipid-packing perturbation of model membranes by $\mathrm{pH}$-responsive antimicrobial peptides \\
\hline 16 & Brazil & Ramos & The role played by modified bioinspired surfaces in interfacial properties of biomaterials \\
\hline 17 & Brazil & Barroso da Silva & Development of constant $\mathrm{pH}$ simulation methods in implicit solvents and applications in biomolecular systems \\
\hline 18 & Brazil & Coutinho & Experimental and theoretical studies of emodin interacting with a lipid bilayer of DMPC \\
\hline 19 & Brazil & Bolean & Biophysical aspects of biomineralization \\
\hline 20 & Brazil & Tedesco & Nano-medicine associated with photodynamic therapy for glioblastoma treatment \\
\hline 21 & Argentina & Alonso & Relationship between biophysical properties of nano-structures and their toxicity on zebrafish \\
\hline 22 & Brazil & Morales & New perspectives in nano-therapeutics for chronic respiratory diseases \\
\hline 23 & Uruguay & Ferreira & $\begin{array}{l}\text { Lead poisoning: acute exposure of the heart to lead ions promotes changes in cardiac function and Cav1.2 ion } \\
\text { channels }\end{array}$ \\
\hline 24 & Brazil & Roque & The role of negative conductances in neuronal subthreshold properties and synaptic integration \\
\hline 25 & Brazil & Kushmerick & Control of neuronal excitability by Group I metabotropic glutamate receptors \\
\hline 26 & Brazil & Naves & Morphological and functional diversity of first-order somatosensory neurons \\
\hline
\end{tabular}

\section{References}

http://www.lafebs.org (n.d.)

http://www.sbbq.org.br/iupab2020 (n.d.)

https://www.thomsonreuters.com/en.html (n.d.)
Morales M, del Valle Alonso S (2014) Successful Latin American initiatives in biophysics. Biophys Rev 2014(6):1-2

Petherick A (2017) Funding: austerity bites deeply. Nature 548(2017): 249251. https://doi.org/10.1038/nj7666-249a Published online09 August 2017 